9. That these propositions should be submitted to the President of the Association of Economic Entomologists.

\author{
D. S. Kellicott, Chairman. \\ L. O. Howard. \\ James Fletcher.
}

The report was adopted, and the officers of the Club were appointed a committee to issue a circular in regard to the Entomological Congress, inviting foreign entomologists to be present at the meeting of the Club next year.

The committee appointed in reference to the preparation of a Manual of Entomology reported progress, and, upon motion, were continued until another year.

The committee appointed to nominate the officers for the ensuing year reported as follows :-

President-Chas. J. S. Bethune.

Vice-President-H. G. Hubbard.

Secretary - C. L. Marlatt.

The report was adopted and the officers elected.

An adjournment was then taken until four p. m.

The Club assembled at four o'clock, and Mr. Weed read the following paper :-

\title{
NOTES ON THE INSECT FAUNA OF THE MISSISSIPPI BOTTOMS.
}

By HOWARD EVARts WeEd, AGRicultural COllege, miss.

Geographically the State of Mississippi is divided into what is known as the hills and the swamps. The hills comprise the middle and eastern portions of the State, while the swamps comprise the western border or the country adjacent to the Mississippi River, the larger portion of which is overflowed every year.

The insect fauna of this region presents many things of interest, there being an absence of many species found in other parts of the State, doubtless owing to the inundation and consequent drowning out in the spring of the year. Indeed, how it is that some of the species which are quite common in this region survive an overflow lasting from three weeks to two or over three months, I leave for others to explain.

As might be expected, in this region there are found but comparatively few species, but these in great numbers. 
It was recently my privilege to visit this region, going by boat from Vicksburg to Greenville, and stopping off for about two weeks midway between these places at Mayersville, in Issaquena County. These notes are not intended to be in any way complete, and I will only mention a few of the more common species, which may be taken as a fair example of the midsummer fauna of this region.

Very few Hymenoptera are here found, and they are, indeed, conspicuous by their absence. Humble bees are exceedingly scarce, and this no doubt accounts for the fact that red clover does not re-seed in this region, as it dies out at least by the end of the third year from planting. But very few honey bees are kept here. The fossores are among the most common hymenoptera, Pelopoeus cementarius, var. architectus, being especially common. Various species of Vespa, Polistes and Halictus are also common.

The Diptera are well represented in many families. The swamps of Mississippi are said to be the land of mosquitoes and gnats, which statement is quite true, the many low places and stagnant pools forming an excellent breeding place for the former, while the rapid running streams and bayous tributary to the Mississippi form a good breeding place for the latter at certain seasons of the year. The Muscidæ are very numerous, the common house-fly being an especial great pest. Very few screen doors and windows are here used, and in many cases the meals during the summer months are served in the open air upon a side porch. In this region during the summer of $\mathrm{I} 890$ the Screw-worm (Compsomyia macellaria) was very destructive to live stock. During the past two seasons, while no cases of injury have been reported, yet the species is quite commonly seen, not only about refuse matter, but, like the house-fly, it is often to be found flying about the table at meal time.

Neuroptera are not common, Libellula pulchella being the only species of the larger dragon flies noticed.

Lepidoptera are not very well represented in this region. Among the butterflies several species of Colias are abundant, while Catopsila eubule and Papilio asterias are occasionally seen. The Noctuidæ are the most common of the Heterocera.

Nearly all the families of the Coleoptera are well represented in this region. As might be expected, the sandy shore along the Mississippi river is a most excellent place in which to collect Cicindelidie. Boats plying the river are furnished with one or two electric lights, which are 
only lit at the landings when freight or passengers are transferred. These lights attract many insects, including several species of Cicindelidæ, which may be easily collected on the deck under the lights. The most common species taken were Cicindela repanda, $C$. hirticollis, $C$. punctulata and C. cuprescens. These species are very common along the river shore, where the sandy strip, extending from the river's edge to the levees, forms an excellent breeding place for them.

The most common insect attracted by the electric lights is the Staphylinid Bledius gularis, which swarms upon the decks in countless thousands. By means of a small shovel I filled a large cyanide bottle full of this species in less time than it takes to tell it. Indeed, so common was the species that the electric lights were turned on only when actually needed at each landing, and by the time another landing was reached the decks would be nearly clear. Very often many of the specimens were trampled under foot and gave out a pecuiiar sickening odour.

Water beetles, especially the Hydrophilidæ, are very common. The family Heteroceridæ is exceedingly common, the most abundant species being Heterocerus ventralis, $H$. undatus, var. limbatus, and $H$. pallidus.

The only Coccinellidæ noticed were Megilla maculata, Hippodamia convergens and Coccinella 9-notata.

Cerambycidæ and Chrysomelidæ are especially common. Lema peninsulce was so thick that large numbers would strike against a person when walking along the levees in the early morning. Flying with this species were large numbers of Disonycha crenicollis and D.pennsylvanica.

Orthroptera are fairly well represented by several species, the most common being Scudderia curvicauda, Dissosteira carolina, Shistocerca americanum, Acridium obscurum, Melanoplus differentialis and $M$. atlanis.

Hemiptera, especially Homoptera, are very abundant. Among the Heteroptera the most common species collected were Amnestus pusillus, Metapodius sp., Leptoglossus phyllopus, Geocoris bullatus and Lygus pratensis, while many species of Notonectidæ and Corisidæ were met with.

Many interesting species of Homoptera are to be found in this region Cicada tibicen is very common, while Clostoptera xanthocephala occurs in large numbers. Other common species are Agallia 4-notata, Diedrocephala mollipes, D. versuta, Chlorotettix viridis and Homalodisca 
triqueta, while the types of Mr. Van Duzee's new species, Anthysanus bicolor, A. obtutus, Deltocephalus flavocastatus, were collected here, $A$. obtutus being especially abundant.

In reply to a question, Mr. Weed stated that he had found no Myriopoda in this region.

Mr. Smith remarked upon the difficulty of obtaining specimens of Lepidoptera from the Southern States. He also stated that some of the species figured by Mr. Abbott had remained unknown until quite recently, and that in the British Museum there were excellent drawings of species undoubtedly new, or, rather, undescribed, and which have not been since found.

Mr. Weed stated that he had been disappointed in regard to the southern fauna, it having been his experience that there were plenty of insects, but comparatively few species.

Mr. Cook followed with a paper entitled "Do Termites Cultivate Fungi ?"

Mr. Hubbard mentioned some of his observations upon Termites in Jamaica, which have been published in the Boston Society of Natural History.

Mr. Cook thought that the so-called fungi masses were only the wood which had been eaten or gnawed off by the Termites. Old Termites do not appear to have anything to do with these masses. The masses of fungi are about four or five inches through, and are not found in the central part of the hills.

Mr. Hubbard stated that these were different from those which he had observed in Jamaica.

The Secretary then read the following paper :-

THE WEB-WORM TIGER (PLOCHIONUS TIMIDUS, HALD).

BY MARY E. MURTFELJT, KIRKWOOD, MO.

It would seem appropriate that this hitherto somewhat rare and inconspicuous little carabid should be brought to the notice of the Entomological Club of the A. A. A. S. in its new role of a benefactor.

I have been observing its habits for two years, and am confident that to it, more than to any other agent, do we, in the neighborhood of St. Louis, owe our present comparative freedom from the Web-worm nuisance. Whereas formerly almost every other tree would, at this season of the year, be infested with one or more of the disfiguring nests, 


\section{$2 \mathrm{BHL}$ Biodiversity Heritage Library}

Weed, Howard Evarts. 1892. "Notes on the insect fauna of the Mississippi bottoms." The Canadian entomologist 24, 276-279.

https://doi.org/10.4039/Ent24276-11.

View This Item Online: https://www.biodiversitylibrary.org/item/18806

DOI: https://doi.org/10.4039/Ent24276-11

Permalink: https://www.biodiversitylibrary.org/partpdf/23519

\section{Holding Institution}

MBLWHOI Library

Sponsored by

MBLWHOI Library

\section{Copyright \& Reuse}

Copyright Status: NOT_IN_COPYRIGHT

This document was created from content at the Biodiversity Heritage Library, the world's largest open access digital library for biodiversity literature and archives. Visit BHL at https://www.biodiversitylibrary.org. 